\title{
Review of the genus Erythria Fieber, 1866 (Hemiptera: Cicadellidae: Typhlocybinae) from Pakistan with description of a newly recorded species
}

\author{
Hassan Naveed ${ }^{1,2^{*}}$, Kamran Sohail ${ }^{3,4}$, Yalin Zhang ${ }^{3}$ and Wen-Jun $\mathrm{Bu}^{2}$ \\ 1. College of Life Science, Leshan Normal University, Leshan, Sichuan 614004-China \\ 2. Institute of Entomology, College of Life Sciences, Nankai University, Weijin Road 94, 300071 Tianjin-China \\ 3. Key Laboratory of Plant Protection Resources and Pest Management of the Ministry of Education, Entomological \\ Museum, Northwest A\&F University, Yangling, Shaanxi 712100-China \\ 4. Department of Entomology, The University of Agriculture Peshawar-Pakistan \\ *Corresponding author's email: hassan.naveed88@outlook.com

\section{Citation} \\ Hassan Naveed, Kamran Sohail, Yalin Zhang and Wen-Jun Bu. Review of the genus Erythria Fieber, 1866 \\ (Hemiptera: Cicadellidae: Typhlocybinae) from Pakistan with description of a newly recorded species. Pure and \\ Applied Biology. Vol. 8, Issue 2, pp1600-1604. http://dx.doi.org/10.19045/bspab.2019.80102
}

\begin{tabular}{llll}
\hline \hline Received: 23/02/2019 & Revised: 29/05/2019 & Accepted: 03/06/2019 & Online First: 08/06/2019 \\
\hline
\end{tabular}

\section{Abstract}

Genus Erythria has only been known from Pakistan with a single species Erythria himalyana Dworakowska 1977. Recently another species, Erythria rudobreva Dworakowska 1993 n. rec., was collected and is redescribed in this paper representing the first country record. Habitus and genital photographs are provided for the first time to provide ready identification. A key is provided to distinguish these known species in this genus from Pakistan.

Keywords: Cicadomorpha; Dikraneurini; Distribution; Hemiptera; Taxonomy

\section{Introduction}

Leafhoppers belong to the largest family within the order Hemiptera, with approximately 22,000 described species in over 40 subfamilies [1-3]. The leafhopper subfamily Typhlocybinae comprises a diverse group of usually tiny, delicate leafhoppers that prefer to feed on the contents in leaf parenchyma cells of their host plants. Species of this subfamily can be differentiated from other leafhoppers in lacking closed preapical cells in the forewing and with the first hind tarsomere acuminate apically. Typhlocybinae consists of over 5,000 described species worldwide, making it the second largest leafhopper subfamily, after
Deltocephalinae [4]. Genus Erythria Fieber, 1866 of the tribe Dikranurini has 23 described species worldwide. This genus is poorly known from Pakistan with only one valid species previously recorded. During an ongoing study of the leafhopper fauna of Pakistan, another species Erythria rudobreva Dworakowska 1993 n. rec. was found to occur in Neelum Valley (Azad Jammu \& Kashmir) and Naran Valley (Khyber Pakhtunkhwa) Pakistan. This discovery is important because this species is rare in its distribution. It is confined to the Indian subcontinent but there is a potential to extend its known geographic range. 


\section{Depositories}

Specimens examined are deposited in the Entomological Museum of Northwest A \& F University, Yangling, Shaanxi, China (NWAFU).

\section{Materials and methods}

Specimens were freshly collected by sweep net in the Neelum Valley, Azad Jammu and Kashmir, the Northern-most portion of Pakistan, located in northwestern part of the Indian subcontinent at $34^{\circ} 35^{\prime} 2.3^{\prime \prime} \mathrm{N}$ latitude and

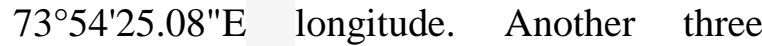
specimens were collected from Naran Valley of Khyber Pakhtunkhwa, Pakistan at 34 54 '33.3"N latitude and 73³9'2.44"E longitude.

Morphological terminology follows Dietrich [5]. Color pattern is described for a specimen in the dry condition. Genitalia were treated with $10 \% \mathrm{KOH}$ solution at $100^{\circ} \mathrm{C}$ for several minutes, rinsed with distal water, immersed in a droplet of glycerol and dissected following standard procedures. All specimens were examined with a Leica ZOOM2000 stereomicroscope. Drawings and photos of genitalia and external morphological features were obtained using a ZEISS SteREO Discovery V20 with a drawing tube. Adobe Photoshop CS was used to compile photographs.

Results and discussion

Erythria Fieber, 1866

Erythria Fieber [6]; Dworakowska [7]

Distant [8], Erythridea Ribaut, 1936 [9]

Basuaneura Ramakrishnan and Menon [10]

Type species: Cicada aureola Fallen [11]

Note: For genus description, see Kang and Zhang [12]

Distribution: China; Nepal; India; Iran; Pakistan; Bulgaria; Romania; Yugoslavia; Poland; Czech Republic; Slovakia; Austria; Germany; Italy; France; Spain; Algeria.
Key to species of Erythria from Pakistan (males)

Pygofer without sclerotized appendages; aedeagus with one pair of apical appendages........................E. rudobreva Pygofer with sclerotized appendages; aedeagus with two pair of apical appendages.......................E. himalyana Erythria himalyana Dworakowska 1977

Erythria himalyana Dworakowska [7].

Material examined: No material available

Distribution: Pakistan, India.

Erythria rudobreva Dworakowska 1993 n. rec. (Fig. 1-10)

Erythria rudobreva Dworakowska [13]

Length: Male 1.7-2 mm; Female 2-2.3 mm.

Coloration and morphology

Greenish yellow to brownish green (Fig. 1). Crown with brownish spots at anterior surface (Fig. 1). Pronotum and scutellum greenish yellow (Fig. 1). Face yellowish brown with brown lateral bands (Fig. 2). Clypeus and anteclypeus with brown spots (Fig. 2). Anterior half of abdomen black dorsally (Fig. 1). Crown slightly produced medially, shorter medially than breadth between eyes. Fore wings may or may not exceed abdomen in dorsal view. Scutellum visible dorsally. Hind wings reduced. Fore wings with cells infuscated, veins lighter and visible (Figs. $1 \& 3$ ).

\section{Genitalia}

Pygofer without sclerotized appendages, rather membranous at posterior margin, with few macrosetae at dorsoposterior margin (Fig. 4). Subgenital plates broad at base, rounded apically, thumb-like with few macrosetae (Fig. 5). Style with preapical lobe slightly truncate, apophysis slightly short and curved, narrowed apically (Fig. 6). Connective ' $T$ '-shaped (Fig. 7). Aedeagus slightly broad at base than apex, with minute denticles along with shaft, shaft with one pair of apical appendages, slightly curved laterally (Figs. 7 \& 8). Abdominal apodemes as shown (Fig. 9). Female: Hind margin of seventh sternite medially notched (Fig. 10). 

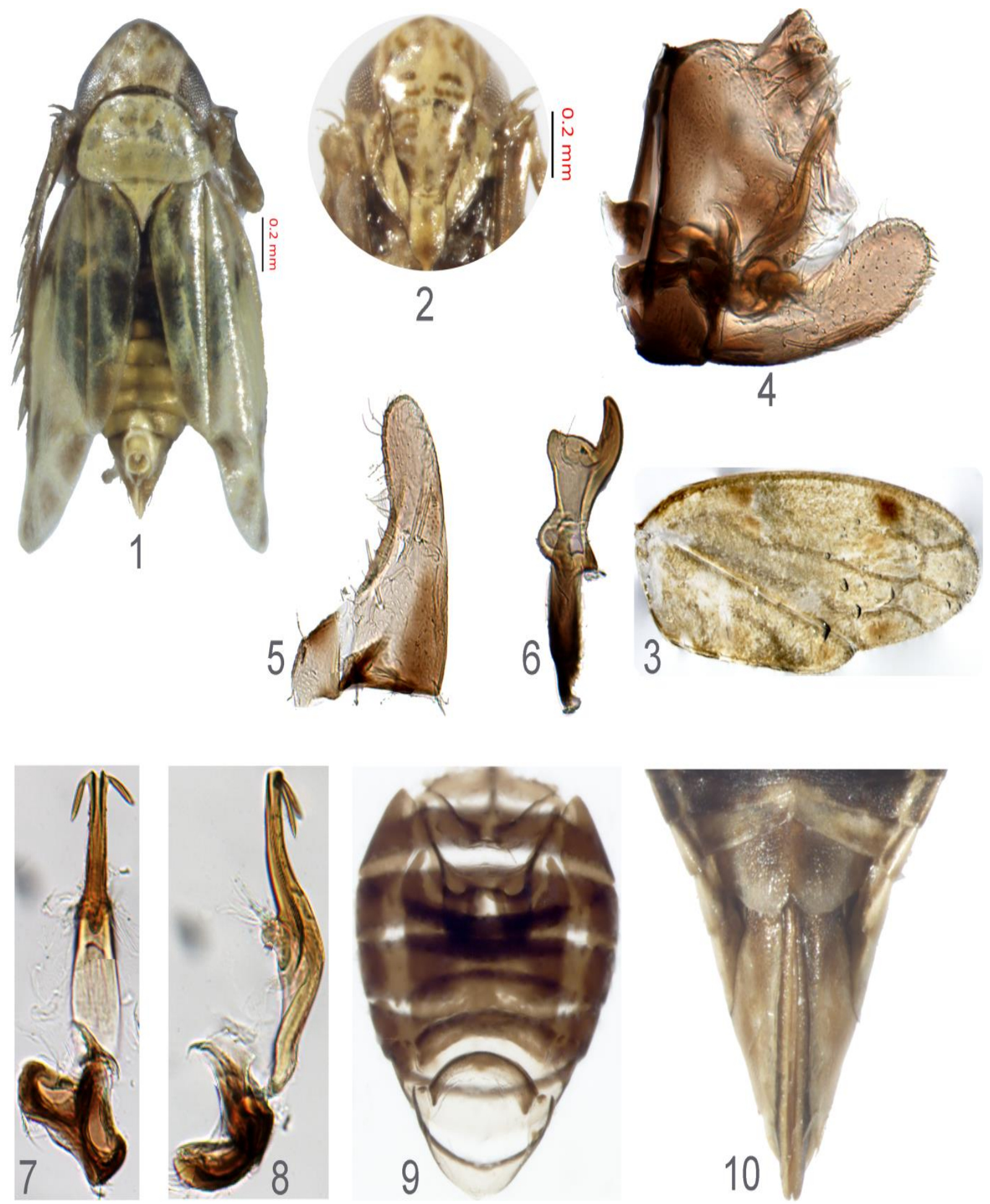

Figures 1-10. Erythria rudobreva Dworakowska 1993. 1, habitus, dorsal view; 2, face; 3, forewing; 4, pygofer, lateral view; 5, subgenital plate, dorsal view; 6, style, dorsal view; 7 , aedeagus and connective, dorsal view; 8 , aedeagus and connective, lateral view; 9, abdominal apodeme, ventral view; 10, female seventh sternite, ventral view 


\section{Material examined}

7ð, 89 Pakistan, Azad Jammu and Kashmir, Neelum Valley, 1386m, 30 July 2018, Coll. Hassan Naveed. $3 q$ Pakistan, Khyber Pakhtunkhwa, Naran, 2461m, August 2018, Coll. Hassan Naveed.

\section{Distribution}

Pakistan, India.

\section{Habitat and behavior}

The specimens were collected from grasses in a mature conifer forest at both localities in the months of July-August.

\section{Conclusion}

We have reported a species Erythria rudobreva Dworakowska for the first time from Pakistan. The identification and description of this new record with habitus and genitalic photographs will serve as an important contribution in the leafhopper fauna of Pakistan. This genus contains 12 species (E. facialis, E. kalimpongensis, E. himalayama, E. vicaria, E. ladaki, E. iranica, E. oculata, E. rudobreva, E. vidanoi, E. calvusa, E. cuspiprojecta, and E. euryprojecta) that occur in Asia. All other species in this genus are found in Europe. This genus was poorly known from Pakistan with a single species. The occurrence of this newly recorded $E$. rudobreva suggests that more efforts are needed to explore this genus from this region in so far as major areas in Pakistan are still under-sampled. We need to make efforts and take responsibility to protect the vanishing biodiversity.

\section{Authors' contributions}

Conceived and designed the experiments: $\mathrm{H}$ Naveed \& K Sohail, Performed the experiments: $\mathrm{H}$ Naveed \& $\mathrm{K}$ Sohail, Analyzed the data: H Naveed, K Sohail, Y Zhang \& W Bu, Contributed materials/ analysis/ tools: H Naveed, Y Zhang \& W Bu, Wrote the paper: H Naveed \& K Sohail.

\section{Acknowledgements}

We are grateful to John Richard Schrock (Emporia State University, USA) for revising the manuscript and making some suggestions. This work was supported by the National Natural Science Foundation of China under grant number (31420103911) and The Ministry of Science and Technology of the People's Republic of China (Grant numbers 2005DKA21402, 2015FY210300).

\section{References}

1. Dietrich $\mathrm{CH}$ (2004). Phylogeny of the leafhopper subfamily Evacanthinae with a review of Neotropical species and notes on related groups (Hemiptera: Membracoidea: Cicadellidae). Syst Entomol 29: 455-487.

2. Oman PW, Knight WJ \& Nielson MW (1990). Leafhoppers (Cicadellidae)-A Bibliography, Generic Checklist and Index to the World Literature 1956-1985. CAB. International Institute of Entomology, Wallingford, pp 368.

3. Zahniser JN \& Dietrich CH (2010). Phylogeny of the leafhopper subfamily Deltocephalinae

(Hemiptera: Cicadellidae) based on molecular and morphological data with a revised familygroup classification. Syst Entomol 35: 489-511.

4. Dietrich CH \& Dmitriev DA (2006). Review of the New World genera of the leafhopper tribe Erythroneurini (Hemiptera: Cicadellidae: Typhlocybinae). Illino Natur Hist Surv Bull 37(5): 119-190.

5. Dietrich $\mathrm{CH}$ (2005). Keys to the families of Cicadomorpha and subfamilies and tribes of Cicadellidae (Hemiptera: Auchenorrhyncha). Flor Entomol 88(4): 10-15.

6. Fieber FX (1866). Neue Gattungen und Arten in Homoptern (Cicadina Bur.). Verhandlungen de Kaiserlich Königlichen Zoolo-gisch-botanischen Gesellschaft in Wien. 16: 497-516.

7. Dworakowska I (1977). On the genus Erythria Fieber (Auchenorrhyncha, Cicadellidae, Typhlocybinae). Bulletin de 
1'Academie Polonaise des Sciences. Serie des Sci Biol 24(10): 597-605.

8. Distant WL (1918). Rhynchota. Homoptera: Appendix. Heteroptera: addenda. The Fauna of British India, Including Ceylon and Burma. 7:1-210.

9. Ribaut H (1936). Homopteres Auchenorhynques I (Typhlocybidae) in Faune de France. 31: 1-231.

10. Ramakrishnan U \& Menon MGR (1971). Studies on India Typhlocybinae (Homoptera: Cicadellidae). 1. Five new genera and a new record of Dikraneurini. Orien Insec 5:455-468.
11. Fallén CF (1806). Fòrsòk till de Svenska Cicad-Arternas uppstàllning och beskrifning. Svenska Vetensk. Akad Nya Handle 27: 6-43.

12. Kang J \& Zhang Y (2012). First records of the leafhopper genus Erythria (Hemiptera:

Cicadellidae: Typhlocybinae) in China, with descriptions of three new species. Zootaxa 3332: 60-66.

13. Dworakowska I (1993). Some Dikraneurini (Auchenorrhyncha: Cicadellidae: Typhlocybinae) from south-east Asia. Orien Insec 27: 151173. 